\title{
Grammatical and Communicative Method - A New Approach in the Practice of Teaching Foreign Languages
}

\author{
Tatyana Vasilyevna Lyubova ${ }^{1}$, Albina Anvarovna Bilyalova ${ }^{1} \&$ Olga Gennadevna Evgrafova ${ }^{1}$ \\ ${ }^{1}$ Kazan (Volga region) Federal University, Naberezhnye Chelny, Russia \\ Correspondence: Tatyana Vasilyevna Lyubova, Kazan (Volga region) Federal University, Mira Avenue, 68/19, \\ 423800, Naberezhnye Chelny, Russia.
}

Received: July 4, 2014 Accepted: September 15, 2014 Online Published: October 30, 2014

doi:10.5539/ass.v10n21p261

URL: http://dx.doi.org/10.5539/ass.v10n21p261

\begin{abstract}
The article discusses the advantages and disadvantages of different methods of teaching foreign languages. A new unique method of teaching foreign languages - grammar and communicative is developed and described. The purpose of this article is a detailed review of the existing diversity of methods of teaching foreign languages in Russia and presentation of the new one - the grammatical and communicative. Recently, learning a foreign language in Russia by the people of different professions has become a necessity due to the rapid growth of contacts with foreign partners. In the process of close cooperation the situations that require training and internships abroad arise, and as a consequence - an indispensable international certification in English. This implies the international exams - TOEFL (Test of English as Foreign Language) or IELTS (International English Language Testing System). It is reported that modern teaching methods have various disadvantages, the main one is the lack of the grammatical material study. The author has developed a grammatical and communicative method and new tutorial which can help to solve this problem successfully. A more comprehensive and in-depth study of grammar is encouraged for students and professionals in order to pass exams for international certification and for further education and training abroad.
\end{abstract}

Keywords: grammar and communicative method, Schechter communicative method, teaching, grammar, international certification

\section{Introduction}

Standard English, which is spoken by different accents, is a dialect and simply one variety of English among many (Trudgill, 1999).The two main varieties of Standard English (SE), which are widely taught to EFL learners in some non-native English-speaking countries, are British English (EngEng) and North American English (NAmEng) (Trudgill \& Hannah, 1992). Native-like performance is still the real goal of language teaching (Sridhar, 1996, p. 64). Therefore, learners of English in outer and expanding circle countries usually seek for British or American native speakers to experience native accents or the standard varieties without considering this variety is actually used or usable in their own context (Kachru \& Nelson, 1996). While native English-speaking teachers (NESTs) can be regarded as speakers of Standard English or a real native speaker model, non-native English-speaking teachers (non-NESTs) may be considered as users of poor English and "bookish language" (Medgyes, 2001). So, lately, the market has been replete with educational technology offers and has been devoid of variation in English teaching methods. The question "What is your teaching method?" has taken the forefront, indicating a recently increased demand for intellectual production. The subject of English teaching methodology has been thoroughly explored by the Russian scholars (Abdulmanova, 1999; Galskova, 2003; Kolesnikov, 2001; Koryakovtseva, 2008; Popov, 2001). In addition, those who wish to learn English, students, and businesspeople are often puzzled while looking through advertisements that promise to enhance English speaking skills: "English in two weeks," "Communicative method of teaching English," "English with native speakers," "Effective rapid method," " English at the subconscious level." With vague taglines and with there being so much new and unknown, doubts about results naturally arise. Can we trust modern technologies? If not, should we give preference to well-established English teaching "brands?" Cambridge, Oxford, Eckersley, and The Headway are all passing into the category of "methodological classics" (Lewis, 1997)

In Russia at the end of the XX century, English language teaching methods underwent a "revolution." Previously, priority was given to grammar, mechanical-like vocabulary learning, reading, and literary translation. These 
principles of the "old school" still bear fruit (as the old methodology is still used in some schools); however, the teachings were routine and monotonous, preventing widespread English fluency. Reading texts, translating passages, memorizing new words, and paraphrasing exercises were tedious regimens occasionally varied by writing, dictation, or phonetic drills that were "breaks" in the routine. In general, when priority is given to reading about and working on a sole topic, only one function of language is implemented- informative. In a massive introduction of linguistic material when prepared structures are remembered in the clearly defined situations, a danger of formal language learning without understanding becomes real. Then the communication at the lesson becomes purely superficial, without affecting the student's personality (Lyubova, 2009). It is not surprising that, with the dated old school method, only a few astutely determined and hardworking pupils were able to achieve English language fluency. Conversely, regarding grammar, all students of the old method could easily compete with Cambridge graduates.

Notwithstanding, in order to achieve commendable results today, much diligence, perseverance, and daily work remain necessary undertakings. The "revolution" has not shortened the road to success; rather, it has made language study more accessible to the majority and, in doing so, a sharpened focus on consumers and their individual goals has emerged. For example, a secretary, an administrative assistant, or a manager with an 8-hour working day spent, as we now say, "exclusively" in the office, should not be burdened with the unnecessary knowledge of the palatalization of consonants or the actual division of English sentences. Such office worker should be focused on developing a certain language knowledge and set of practical skills: thus, the creation and modern consumption of particular segments of English teaching and learning comes to light. Comprehensive, topic-spanning approaches are not efficient or effective when only a fragment of language study is necessary. Renowned expert in the field of linguistics and language teaching methodology S.G. Ter-Minasova (Ter-Minasova, 2000) rightly notes that nowadays, the study of language has become more functional, "The unprecedented demand has demanded an unprecedented proposal. Unexpectedly, foreign language teachers appeared at the center of public attention: the legions of eager professionals in various fields of science, culture, business, technology and all other areas of human activity demanded an immediate foreign language teaching as an instrument of production. They are not interested neither the theory nor history of a language. Languages, primarily English, are required only practically for use them in different spheres of society as a means of real communication with people from other countries". The problem in question have been investigated by many distinguished scientists (Anosova, 2001; Koryakovtseva, 2008; Harmer, 2001; Lozanov, 1979)

Situation with the form of training has become much easier: the departure to the office, one-on-one sessions with a teacher, coming to a student's house, " weekend "groups, the various types of educational courses, additional higher education.

But we should solve the main questions: what is the content of the course, what is its structure and methods of teaching? Who is the author of the material? Where this material is designed and tested?

Language teaching has become an applied character, whereas earlier it used to be relatively abstract and theorized. Aristotle gave the famous triad of teaching ethics, which is perfectly correlated with the modern requirements: (1) logo - the quality of presentation; (2) pathos - the contact with the audience; and (3) ethos attitude towards others. This rule applies to the speaker, an actor and the teacher of a foreign language, whose roles involve two first hypostasis. Lately the functions of the teacher in the educational process have changed considerably. The teacher - mentor is unable to offer students freedom of choice and provide, the necessary in comprehending such a subtle matter, as a language, "academic freedom". In this case, one of the central problems is the mutual coordination of interlocutors freedoms, when no one can put a pressure on anyone, but has the right to appeal to somebody, and to be heard by him. So we must learn to be yourself and express yourself without suppressing by the other. This principle is very important in the learning process itself, and also in particular, in the foreign language classes, where the interaction between teacher and student is the mutual coordination of communication rights. Therefore, the negative image of teacher-mentor is gradually becoming a part of history. He was replaced by the teacher-observer, teacher mediation, teacher-leader. Although in this case, the teacher's personality is inconsequential, his influence on the audience, which, in turn, becomes more intimate, not decreases, but increases greatly. It is the teacher who, for most Russian and foreign educational courses, is the organizer and overseer of group interaction. Good teachers should have "a love of the English language" (Brown, 2001), be sensitive to the current change of language teaching and have knowledge of a wide variety of English language (McGroarty, 1996). Attitude and motivation on language teaching often affect both learners and teachers readily and unconsciously (McGroarty, 1996). McGroarty also notes that wise teachers should make effort to discover the facts that sharpen motivation in the specific situation in which they work. 
Progress, variability and fundamental changes in the methods of language learning are undoubtedly related to innovations in the field of personality psychology and group. Today we can feel a noticeable change in the minds of people and the development of new ways of thinking: there is proclaimed Maslow's need for self-actualization and self-realization. The psychological factor of learning foreign languages is promoted to the leading positions. Authenticity of the communication, the weighted demands and claims, mutual benefit, respect for freedom of others - this is a set of unwritten rules of forming a constructive relationship in the system "teacher-student". Learners' need analysis which emphasizes on discovering motivation, and psychological and social needs, rather than on making lists of individual communicative needs or linguistic items (Seedhouse, 1995) should be conducted precisely during the English course.

Next, but not less important element of the system is the choice. It appeared when a student can attend a course that meets his needs. In the classroom the student is no longer limited in the choice of speech means and his own verbal behavior. The teacher is also not constrained in the choice of methods and techniques of teaching - from games and training sessions to interpretation, in the organization of classes, in the selection of textbooks and tutorials - from a wide range of the domestic products to Oxford, Cambridge, London, New York and Sydney editions. The teacher can now choose, create, combine, modify.

Despite the existing variety of techniques, they all have some drawbacks. We'll talk about them a bit later.

As already noted, in the current system of globalization, so called "world without borders", the need to know a foreign language at a high level is essential but it is not enough to speak and understand well. For training and professional training abroad the international certificate (IELTS, TOIFL), which confirms the high level of language knowledge of the applicant, is required. The procedure of the exam for international certificate consists of a phased test, which consists not only of practical skills (writing, speaking and perception of foreign language at the hearing), but also of the theoretical knowledge of grammar verification. And here we are faced with a problem: the communicative method of teaching a foreign language, which has recently established itself as the best in teaching speaking and listening, does not imply a serious study of the grammatical material, but the last one is essential to pass the exam for international certification successfully. In the tutorials, built on the principle of the communicative method, we find only some brief commentaries on the fundamental questions of grammar.

All these factors have brought us to the need to develop a new concept, namely, a new method of teaching a foreign language - "grammatical and communicative.

\section{Methodology}

In the process of the development of grammar and communicative method we used a variety of methods of pedagogical research. Namely, at the initial stage - analysis, the methods of questioning and testing, at the intermediate - pedagogical and piloting experiments, projective techniques, synthesis, at the final stage - ranking methods, teacher consultation, and a control experiment were applied. Moreover in the development of the method of teaching foreign languages we decided to use an unconventional approach and in addition to the empirical methods of pedagogical research it was used a theoretical one - modeling. Modeling, as it is known, is based on a synthetic approach: holistic systems are delaminated and their functions are studied. We carefully worked out all the stages of modeling, starting with the construction of the model, its experimental analysis, comparison of the results of the analysis and the characteristics of the original, detection any inconsistency between them, model adjustment, interpretation of the obtained information, explanation of the discovered properties and relations; and finally practical test of simulation results.

\section{Results}

Grammar and communicative method also goes back to Lozanov's suggestopediya (Losanov, 1979), uses many elements of the methods Schechter (WMS, 2014) and Kitaygorodskaya (Kitaygorodskaya, 2009) and is based on the communicative method. However, we were guided by the following principles:

(1) grammar-communicative method should be universal. It should be well suited for both classes with students of certain specialties, and for professionals.

(2) The method must reconcile all the existing methods of teaching the language. In each session there is a phonetic training (5-10 min. depending on the level), the theory of grammar (15-20 min), conversational grammatical training (30 min.) and communication training (1 hour).

(3) Students should be clearly focused on a specific goal and have a full understanding of what they do.

(4) The method should encourage teachers to maintain a professional level of knowledge of the language and take regular refresher courses. 
(5) There must be a principle of continuity. The educational process must be continuous. Material learned in one lesson is the base for the next study.

We have developed a selection of grammar material - the author's tutorial, a new educational curriculum, and that it registered as a "know- how" by the patent department of the Kazan Federal University and is considered its intellectual property.

In short we can characterize the grammatical and communicative method as the quintessence of the popular modern methods of teaching English. Relying on high grammar course, we teach students to speak, read, write, and translate. The use of multimedia tools, educational materials «Oxford» and «Cambridge», reinforced teaching of grammar - all that together is recognized as a new methodological solution.

\section{Discussion}

Now we explain the topicality of developing a new method by considering the advantages and disadvantages of some of the existing analogues. The subject of English teaching methodology has been elucidated by a wide range of English scholars (Allen, 2003; Lewis \& Hill, 1997; Thornbury, 2010; Schmitt, 2008).

One of them - "grammar-translation or a traditional method" of teaching English. According to this method, knowledge of the language means to know grammar and vocabulary. The improvement process is understood as a movement from one grammar scheme to another. Thus, a teacher who is planning an English training course on this method, firstly should think about grammatical scheme he wants to highlight. Then, texts under these topics are selected, from them are extracted some separate sentences, and the process of training ends with an extracted sentences translation. First - from foreign language to native, then vice versa. As for the text, it is usually called artificial text in which virtually no value is given to the meaning: not so important what you say, the point is how you say it. Catching up on the classical method, the students not only operate a wide variety of lexical layer, but also learn to see the world through the eyes of "native speaker" (Koryakovtseva, 2008).

Proponents firmly believe that language loses life when teachers and students aim to acquire a "lifeless" lexical and grammatical forms. Someone said that "a person - is a product of culture." Language - as well. And it convincingly confirm our language mistakes. The student may use any English grammatically correct expression of The Queen and Her relatives, but the British could hardly understand what they mean. Actually, the correct variant here is The Royal Family. Or, for example, such a phrase as "hero - is the spokesman of the author's ideas" were translated as "The hero is the loudspeaker of the author "(" loudspeaker of the author "), which ideally wanted to be used as "mouthpiece". Such oddities are common. Turn to the more subtle matter: for example, if our compatriot, superficially know the language, the difference between the expressions "Don't you want to go?" and "Would you like to go?" is not very large, it is principled for the British, because the first he perceives as not the best tone. Familiar to our business communication "What issues are you interested in?" is often translated as "What problems are you interested in?" without matter that the English word "problems" has negative meaning. Correct question will be heard as: "What issues are you interested in?" (Lewis \& Hill, 1995)

The main disadvantage, of course, is that the traditional method creates ideal conditions for the so-called language barrier, so the man in the learning process stops expressing himself and doesn't speak, but simply combine words by certain rules.

There is also another alternative it is the method of emotional and semantic approach created by Schechter. Schechter technique implies free communication of a teacher and students from the first classes. Full immersion in the language. Students choose their nicknames which are traditional to the natives of studied language and the corresponding "legend" - architect of Glasgow, a violinist from Palermo, etc. The essence of the method is that the phrases and word constructions are remembered naturally. It is widely-known that presentation of new language items should be immediately followed by their practice. New knowledge needs to be integrated into existing knowledge, i.e. the learner's existing network of word associations, what is called the mental lexicon (Lozanov, 1979).

This method has a couple of disadvantages: first, it is not suitable for studying in the mode of 2-3 times per week (i.e. "Business studies by the method of Schechter" is not simply possible), second, though people start talking very quickly, the grammar they have is weak. Later, Schechter introduced in his method a two-week "grammar sessions" where students are engaged in the study of grammatical rules exclusively.

In practice of teaching a foreign language there is a prototype of our method called "communicative approach", which is currently the most popular. Communicative method suggests to develop the ability to think in the target language in real-life circumstances. The teacher models the lesson as various communication situations, and 
encourages students to participate. Thus, the students are stimulated by the desire to speak out. This enables the communication not only between the teacher and students, but among students themselves.

Students are offered the tasks, in the course of which they can systematically develop all the basic language skills (listening, speaking, reading and writing). The main place in the communicative method of foreign language teaching occupies game situations, work with a partner, the task to search mistakes that let you build up the vocabulary and teaches to think analytically.

The communicative approach is based on the assertion that for the successful study of a foreign language students need to know not only the linguistic forms (i.e. grammar, vocabulary and pronunciation), but also have an idea of how to use them for the purpose of real communication.

Still, the weak link of the communicative method is the study of grammar. Many people believe that the grammar will be acquired automatically, it means that there is no need to study it separately. However, it is not fair. The study of grammar in the communicative method of teaching should occupy $30 \%$ of the study. But this knowledge is given unsystematically, often is presented in the form of a short comment. As a result, the student doesn't understand the logic of language, and can't use it in full.

Another serious drawback is the ignoring by the teacher the students errors. We, like the most of today's teachers are of the opinion that we should learn to speak correctly, not somehow. In addition, according to well-known method is Penny Eure, in recent years, students ask the teachers to correct speech errors, because they are planning to pass the international exam or get a good job, or enter the university. Where the language knowledge should be much more fundamental than just a fluent speaking.

Known prototype, that is, the communicative method can't be applied in the courses "Business English for Professionals", as it does not provide a decent level of knowledge of a foreign language. With a good level of the spoken language we can see apparent gaps in knowledge of grammar, and that is a serious obstacle to the passing of the interview in a foreign company or the examinations for international certificate. Matsuda (cited in Baumgardner, 2006) notes that an incomplete presentation of English language may lead learners to frustration and demotivation.

\section{Conclusion}

The method was successfully tested on the educational basis of Naberezhnye Chelny Institute (branch) of Kazan Federal University. Students from different specialties, studied according to our method, when testing, showed a high level of knowledge not only in the practical language skills, such as speaking a foreign language and listening, but also a strong knowledge of grammar.

Thus, we can conclude that the use of this method can satisfy the need for professional education of a foreign language of specialists and students at a higher level.

Wherein new approaches to teaching a foreign language suppose that English language as a discipline should be an integral component of modern specialist training.

Unfortunately we were not able to cover all aspects of grammar equally well, so the designed grammatical tutorial needs to be improved. In addition, we could not find a reasonable balance between the teaching of all aspects of language, such as - speaking, listening, reading and writing so as a priority in our methodology is given to grammar and speaking. In the proposed program of study there is a clear lack of training exercises in reading and writing, these imperfections are the main tasks, requiring further refinement. Thus, we'll have a lot of work to be properly done in order to make our know-how more universal.

\section{References}

Abdulmanova, M. V. (1999). The original techniques and traditional benefits for English lessons (pp. 223-248). Russian Teacher of the Year: The Best of the Best. Publishing center VLADOS.

Allen, V. F. (2003). Techniques in Teaching Vocabulary (p. 136). Oxford: Oxford University Press.

Anosova, N. E. (2001). Features of the new perception of foreign words in the context (pp. 22-25). Methodology of teaching at the university, St. Petersburg: St. Petersburg State Technical (issue 3).

Baumgardner, R. J. (2006). Teaching World Englishes. In B. B. Kachru, Y. Karchru, \& C. L. Nelson (Eds.), The handbook of World English (pp. 661-671). Oxford: Blackwell Publishing Ltd. http://dx.doi.org/10.1002/ 9780470757598.ch36

Brown, H. D. (2001). Teaching by principles: An interactive approach to language pedagogy (p. 429). New York: Pearson Education. 
Galskova, N. D. (2003). Modern methods of teaching foreign languages: A guide for teachers (p. 192). Moscow: RKTI.

Harmer, J. (2001). How to Teach English (p. 181). St. Petersburg: Pearson Education Limited.

Introduction to the communicative method of teaching English (p. 48). (1997). OUP.

Kachru, B. B., \& Nelson, C. L. (1996). World Englishes. In S. L. McKay, \& N. H. Hornberger (Eds.), Sociolinguistics and Language Teaching (pp. 71-103). Cambridge: Cambridge University Press.

Kitaygorodskaya, G. A. (2009). Intensive language training: Theory and practice (p. 280). Moscow: High school.

Kolesnikov, I. L., \& Dolgina, O. A. (2001). Anglo-Russian glossary of terms for the teaching of foreign languages (p. 224). St. Petersburg: Publishing House of the "Russian-Baltic Inform. Center "Blitz", "Cambridge University Press".

Koryakovtseva, N. F. (2008). Modern methods of self-organization of foreign language learners: A guide for teachers (p. 175). Moscow: ARKTI.

Language and intercultural communication: Tutorial. Retrieved January 16, 2014, from http://www.gumer.info/ bibliotek_Buks/Linguist/Ter/_Index.php

Lerning language English Fundamental method. Retrieved January 27, 2014, from http://www.college-training. ru/lang/english/74

Lewis, M. (1997). Implementing the Lexical Approach (p. 187). N.Y.: Language Teaching Publications.

Lewis, M., \& Hill, J. (n. d.). Practical Techniques for Language Teaching (p. 135). London: Language Teaching Publications.

Lozanov, G. (1979). Suggestopediya in the teaching of foreign languages. Methods of intensive foreign language training, 5, 175.

Lyubova, T. (2009). Realization of the axiological approach in the process of the development of intercultural competence of students (from the example of learning a foreign language). (Unpublished dissertation for the degree of Candidate of pedagogical sciences). Kazan Federal University, Kazan.

McGroarty, M. (1996). Language attitudes, motivation, and standards. In S. L. MacKay, \& N. H. Hornberger (Eds.), Sociolinguistics and Language Teaching (pp. 3-47). Cambridge: Cambridge University Press.

Medgyes, P. (2001). When the Teacher is a Non-native Speaker. In M. Cele-Murcia (Ed.), Teaching English as Second or Foreign Language (pp. 429-434). Boston: Heinle \& Heinl.

Native English. Retrieved January 23, 2014, from http://enative.narod.ru/theory/methods/prepod.htm

Need analysis and the General English classroom. Retrieved March 20, 2014, from http://www.faculty.ksu. edu.sa/yousif/Course \%20content\%20for\%20CI\%20584/Seedhouse-needs\%20analysis.pdf

New teaching and information technology in education (p. 271). (2001). Moscow: Publishing center "Academy".

Popov, I. M. (2001). Optimization of foreign language teaching in the professional training of students of a technical college. Unpublished dissertation in partial fulfilment of the requirements for the degree of Candidate of pedagogical sciences, St. Petersburg State Technical University, St. Petersburg.

Schmitt, N. (2008). Vocabulary in Language Teaching (p. 234). Cambridge: Cambridge University Press.

Standard English: What it isn't. Retrieved February 23, 2014, from http://www.phon.ucl.ac.uk/home/dick/ SEtrudgill.htm

Thornbury, S. (2010). How to Teach Vocabulary (p. 321). London: Pearson Education Limited.

Trudgill, P., \& Hannah, J. (1992). International English: A Guide to Varieties of Standard English. London: Edward.

What is method Schechter? Retrieved February 2, 2014, from http://www.shekhter-method.narod.ru/

\section{Copyrights}

Copyright for this article is retained by the author(s), with first publication rights granted to the journal.

This is an open-access article distributed under the terms and conditions of the Creative Commons Attribution license (http://creativecommons.org/licenses/by/3.0/). 